\title{
Evolution in the profile of thyroid cancer cases treated in an oncology reference service: what changed in the last 20 years
}

\author{
Evolução no perfil dos casos de câncer de tireoide tratados em um serviço de \\ referência em oncologia: o que mudou nos últimos 20 anos
}

Renan Bezerra Lira, MD'; Genival Barbosa de Carvalho, MD'; João Gonçalves Filho, TCbC-SP, MD, PhD'; Luiz Paulo

KOWALSKI,TCBC-SP, MD, PHD ${ }^{1}$

A B S T R A C T

\begin{abstract}
Objective: To evaluate the characteristics of thyroid carcinoma cases treated at a reference hospital for cancer between 2008 and 2010. Methods: we studied 807 cases and analyzed the following clinicopathologic variables: symptoms, risk factors, diagnostic tests, staging, histological type, treatment performed and complications. Results: Females were more affected, with 660 cases (82\%). The average age at diagnosis was 44.5 years. Prior exposure to ionizing radiation was reported by 22 (3\%) patients, a family history of thyroid cancer by $89(11 \%)$, and $289(36 \%)$ individuals reported other types of cancer in the family. The fine needle aspiration biopsy was the main parameter for surgical indication and was suggestive of carcinoma in 463 patients (57\%). Papillary carcinoma was the most common histological type, with 780 cases $(96.6 \%)$. There were 728 (90\%) total thyroidectomies, $43(5.3 \%)$ reoperations or partial thyroidectomies followed by totalization, $23(2.8 \%)$ extended thyroidectomies and only $13(1.6 \%)$ partial thyroidectomies (lobectomy with isthmectomy). Neck dissection associated with thyroidectomy was done in 158 patients (19.5\%). We observed a predominance of tumors classified as T1 in 602 (74.6\%) patients. Transient hypocalcemia was the most frequent complication. Conclusion: The results show that the worldwide increase in the incidence of thyroid cancer has changed the profile of patients seen at a referral service. In addition, there were changes in the type of surgical treatment used, with increased use of total thyroidectomy in relation to partial and subtotal ones, and decreased use of elective neck dissections.
\end{abstract}

Key words: Thyroid gland. Thyroid neoplasms. Adenocarcinoma. Thyroidectomy

\section{INTRODUCTION}

$\mathrm{M}$ alignant neoplasms of the thyroid are, among all types of cancer, the fastest growing in incidence in recent years, according to the analysis of the US SEER database'. This incidence has nearly tripled in the last 30 years, from 4.3 cases per 100,000 people in 1973 to 11.1 cases per 100,000 in 2006 . The growth was even higher for the thyroid papillary carcinoma, which had an increase of 3.2 times in the same period and currently represents $90 \%$ of all thyroid malignancies. Mortality from thyroid malignancy, however, remains stable in the US ?.

In Brazil, although estimates published by INCA also point to an increased incidence of this disease, there is no precise data published about the variation in the occurrence of thyroid cancer in the recent years. However, thyroid cancer, which was not among the most frequent malignancies, represents today $5 \%$ of cases diagnosed in women, with an estimated 11 cases per 100,000 Brazilian women in 2012, the fourth most frequent malignancy². A timely analysis of the incidence and mortality of thyroid cancer in our country showed large regional variation, likely secondary to differences in accessibility to diagnostic methods and coverage of cancer registries, as well as a decrease in mortality in the last two decades of the past century ${ }^{3}$.

There is still are discussion whether the increased incidence observed in different parts of the world is real or relative due to diffusion and greater use of diagnostic methods, particularly ultrasound (US) and fine needle aspiration (FNA), as well as increased detection of microcarcinomas in patients operated on for benign diseases ${ }^{4}$. Recent analyzes point to an increase in the number of cases diagnosed with tumors of all sizes, including tumors larger than $5 \mathrm{~cm}$ (12\% per year), besides, obviously, microcarcinomas ( $19.2 \%$ per year) ${ }^{1,5}$, and some differences in this rate of growth in ethnic and age subgroups, suggesting that there is indeed a real increase, attributable not only to the improvement of medical care and diagnostic methods ${ }^{6-9}$.

1. Department of Head and Neck Surgery and Otorhinolaryngology, AC Camargo Cancer Center, São Paulo - SP, Brazil. 
The treatment of thyroid cancer is surgical in most cases, with rates of disease-free survival at five years of 9097\% for papillary carcinoma, 99.8\% for localized tumors, $97 \%$ for regionally spread tumors and $57.3 \%$ for tumors with distant metastases ${ }^{10}$. The main prognostic factors are age and the presence of extrathyroidal extension. For the well differentiated carcinoma subtypes, the method of resection (total or partial) does not seem to affect treatment outcome, though total thyroidectomy has been increasingly used in recent years. The association of neck dissection and adjuvant radioiodine are matters of constant debate, both lacking level I evidence to be formally indicated. According to the last consensus of specialist societies in thyroid disease, neck dissection is indicated only in the presence of clinically detectable nodal disease ${ }^{11-18}$. Adjuvant radioiodine therapy should be administered in high-risk patients and avoided in low-risk ones, and may or may not be used in moderate risk cases ${ }^{11,18,19}$. This study analyzes the changes in the pattern of thyroid cancer cases treated at a cancer reference hospital, correlating them with epidemiological, clinical and pathological changes, as well as treatment employed.

\section{METHODS}

This is a retrospective cohort study with clinical, epidemiological, histopathological and therapeutic data collected through review of the electronic medical records of all patients operated on for thyroid cancer in the Department of Head and Neck Surgery and Otorhinolaryngology, AC Camargo Hospital, from January $1^{\text {st }}, 2008$ to December 31 $31^{\text {st }}, 2010$. We collected information regarding these patients age, gender, symptoms, risk factors, diagnostic tests, staging, histological type, treatment performed and complications. The results were compared with data available in a previous publication of cases treated between 1990-200020.

\section{RESULTS}

In the 807 cases of treated thyroid cancer included in this study, females were most affected, with 660 cases (82\%) versus $147(18 \%)$ males. The average age at diagnosis was 44.5 years (median 45), ranging from 10 to 96 . Among the risk factors studied, previous exposure to ionizing radiation was reported by $22(3 \%)$ patients, and family history of thyroid cancer by 89 (11\%). In addition, $289(36 \%)$ patients reported other types of cancer in the family. Preoperative FNA was the main parameter for surgical indication. In this sample, 463 patients (57\%) had FNAB suggestive of carcinoma and 222 (28\%), of follicular disease. The remaining procedures were indicated for other reasons, 76 (9\%) without FNA, 37 (5\%) with benign cytology and nine (1\%) with cytology unsatisfactory for diagnostic. In these patients surgical treatment was indicated by other parameters such as compressive symptoms, aesthetic reasons, progressive growth of nodules, hyperparathyroidism or desire of the patient.

Papillary carcinoma was the most common histological type, with 780 cases (96.6\%). There were six follicular carcinomas and four simultaneous follicular and papillary carcinomas, totaling $97.9 \%$ (790) of the well differentiated tumors. Sixteen patients were operated with medullary carcinomas (two cases with simultaneous papillary carcinoma) and one anaplastic carcinoma, with simultaneous papillary carcinoma.

As for the type of operation performed, there were $728(90 \%)$ total thyroidectomies, 43 (5.3\%) reoperations or partial thyroidectomies followed by totalization, $23(2.8 \%)$ extended thyroidectomies and 13 (1.6\%) partial thyroidectomies (lobectomy with isthmectomy). Neck dissection associated with thyroidectomy was done in 158 patients (19.5\%). Of these, 129 were subjected to dissection of the central compartment, 26 to dissection of the central and lateral ones (grades II-V), and only three to lateral neck dissection (associated with the exploration of the central compartment) (Table 1).

We observed a predominance of tumors classified as T1, with 602 (74.6\%) cases (Figure 1). Regarding lymph node involvement, 90 cases were staged as pN1a, and 29, as PN1B. In 39 cases no metastatic lymph nodes were identified ( $p N 0)$. Multifocality was observed in 229 cases (37\%) and extraglandular extension in 121 (15\%).

Postoperative complications occurred in $22.1 \%$ of patients, the most common being: transient hypocalcemia ( $<6$ months) in $7.9 \%$, transient paresis of vocal cord $(<6$ months) in $5.7 \%$, permanent hypocalcemia in $2.6 \%$ and permanent vocal cord paresis in $1.5 \%$. Other less common complications were hematomas $(0.4 \%)$ and wound infection $(0.6 \%)$.

Adjuvant radioiodine therapy was prescribed in 543 (67\%) patients based on individual risk rating.

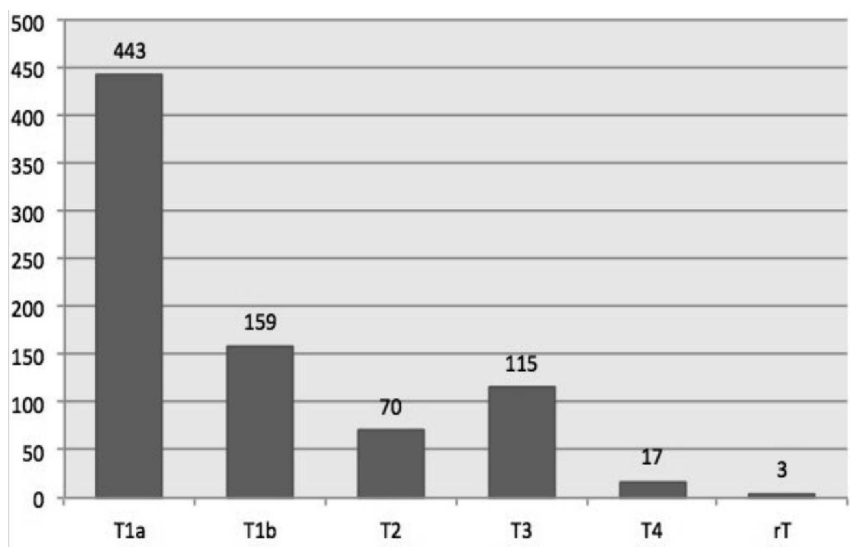

Figure 1 - Pathological Staging: TNM. 


\section{DISCUSSION}

In 2010 1,285 operations were performed in the Department of Head and Neck Surgery, with average, between 2008 and 2010, of 440 thyroidectomies per year, 269 due to cancer. In 1990, 725 operations were performed in this department, only 44 thyroidectomies, 12 due to cancer. Between 1990 and the period from 2008 to 2010, there was an increase of $77 \%$ in the total number of operations, especially those related to the treatment of thyroid diseases, which increased more than $1,000 \%$. When analyzing the numbers of admission and treatment of patients with thyroid cancer in the same period, we observe an increase of $2,766 \%$, from 12 cases in 1990 to 344 cases in the year 2010. This increase in the number of thyroid cancer cases is the major cause for inversion of gender in the number of patients treated for cancer in the Department: In 1990, we treated three men for every woman (3:1), and, in 2010, that ratio was balanced (1:1) ${ }^{21}$. When we compared the previously published series of the same Department, with 316 cases treated between 1990-200020 with the series of 807 thyroid malignancies treated within three years of this study, we observed no difference in the distribution by gender, with women being more affected in both series $(83.2 \%$ vs. $82 \%$ ). However, there was an increase from $88 \%$ (276 out of 316 ) to $96.6 \%$ (780 out of 807 ) of the predominance of papillary carcinoma over the other histological variants, such as follicular carcinoma, which was diagnosed in only $1.3 \%$ of patients in this study compared with $12 \%$ in the 90s, which coincides with the changes in this profile already published in other studies ${ }^{1,4,22}$. Another important change in the treated patients was the decrease in the relative number of patients with clinical diagnosis of lateral cervical metastases (level IV) on admission, from 19.6\% (62 out of 316 ) to $3.6 \%$ (29 out of 807 ), which reflects the increased incidence of thyroid cancer reported in the literature, mainly at the expense of early stage tumors, and maintaining the same levels of mortality despite this increased incidence ${ }^{22}$. We could also see changes in therapy employed over the past decades by the same group of experts dealing with the same disease. Currently total thyroidectomy is used in $90 \%$ of cases ( 728 out of 807 ) and partial thyroidectomy only in benign unilateral nodular disease or microcarcinomas, of very low risk, found after resection in the histopathological final analysis (the others are led to totalization), being held in $1.6 \%$ (13 out of 807) of patients in the most recent series, much less than in the 90s, when it was performed in $92(29 \%)$ patients. In addition, neck dissection of the central compartment, which was performed in $38.9 \%$ (123) of patients in the late 90 's, is being used less often, since only $16 \%$ (129) of cases underwent this surgical complementation in recent years. This is probably due to that currently we only indicate prophylactic central compartment dissection in locally advanced tumors (T3 and T4), which are becoming relatively less frequent in our service, whereas during the 90s was this its. Indication was broader

When evaluating these two series of patients consecutively treated in the same Brazilian reference service for head and neck surgery, there were significant changes in the profile of presentation of thyroid cancer in recent decades. In addition to the rapid growth in the absolute number and relative to other cancers of the head and neck, thyroid cancer is now increasingly diagnosed at earlier stages and in its more indolent subtype, papillary carcinoma, as demonstrated by Simard et al., who showed an increase in the incidence of thyroid cancer in all races, all age groups and both sexes, however, much more pronounced as localized tumors ${ }^{10}$.

The operative treatment used has also changed, with more frequent use of total thyroidectomy, which has become the standard treatment in recent years, in relation to partial thyroidectomy or lobectomy, which, according to the consensus of the American Thyroid Association, of the Latin America thyroid Society and Brazilian Consensus, is now only considered sufficient treatment in cases of papillary carcinoma diagnosed after surgery, of less than $1 \mathrm{~cm}$, limited ti the thyroid, without adverse pathologic factors, without nodules in the contralateral lobe and in patients without a family history of thyroid cancer or prior exposure to radiation, ie, much selected cases. In all cases with a preoperative diagnosis of carcinoma, the recommended treatment is total thyroidectomy ${ }^{11,18,19}$. This trend is driven by the more frequent recognition of postpartial thyroidectomy hypothyroidism, both in our experience (not yet published) and in several other analyzes 19,23-27 and also by the advantage of enabling the adjuvant radioiodine therapy when indicated, and the more accurate use of serum thyroglobulin and whole body scan with $I_{131}$ during postoperative follow-up, without increased risk of complications $^{28}$. The treatment of nodular thyroid disease in our Department routinely involves intraoperative frozen biopsy. Thus, in patients with an indication for thyroid surgery, we only performed partial thyroidectomy (lobectomy with isthmectomy) when the contralateral lobe had no nodules, the patient was euthyroid preoperatively, and examination by frozen biopsy of the removed specimen showed no evidence of malignancy. Another evolution we noticed in the treatment employed in our patients is the more conservative use of prophylactic neck dissection of the central compartment, following the trend proposed by the latest consensuses, recommending this type of dissection only in the presence of detectable metastases, both clinically or in pre or intraoperative, and in T3 and T4 tumors (TNM). In other cases, only the exploration of the level $\mathrm{VI}$ is sufficient to achieve the therapeutic neck dissection in the presence of metastases confirmed by frozen biopsy ${ }^{11,19}$

The rapid increase in the incidence of thyroid cancer associated with survival rates at five years higher than $95 \%$ has, in most cases, the potential to generate 
significant changes in the demand for centers and trained physicians for treatment and especially follow-up of this large number of survivors of this neoplasm ${ }^{10}$.

We observed, therefore, that the worldwide increase in the incidence of thyroid malignancy altered the profile of patients seen at a referral hospital for cancer in Brazil21, with growth in number, especially for localized tumors, which, although requiring relatively lower neck dissections, were treated mostly with total thyroidectomy, an influence of the evolution in knowledge about treatment of this cancer. The current head and neck surgery services with multiprofessional teams must adapt to this evolution profile, where thyroid cancer has been increasing, incorporating endocrinologists and nuclear medicine physicians as effective members and with significant role in teams.

\section{R E S U M O}

Objetivo: avaliar características casos de carcinoma de tireoide atendidos em um hospital de referência em câncer entre 2008 e 2010. Métodos: foram analisadas variáveis clínico-patológicas de 807 casos tratados em três anos: sintomas, fatores de risco, exames de diagnóstico, estadiamento, tipo histológico, tratamento realizado e complicações. Resultados: o sexo feminino foi o mais acometido com 660 casos (82\%). A média de idade ao diagnóstico foi 44,5 anos. A exposição prévia à radiação ionizante foi referida por 22 (3\%) pacientes, a história familiar de câncer de tireoide por 89 (11\%) pacientes e 289 (36\%) pacientes relataram outros tipos de câncer na família. A punção aspirativa por agulha fina foi o principal parâmetro para indicação operatória e foi sugestiva de carcinoma em 463 pacientes (57\%). O carcinoma papilifero foi o tipo histológico mais incidente, com 780 casos (96,6\%). Foram realizadas 728 (90\%) tireoidectomias totais, 43 (5,3\%) reoperações ou tireoidectomias parciais seguidas de totalização, 23 $(2,8 \%)$ tireoidectomias ampliadas e apenas $13(1,6 \%)$ tireoidectomias parciais (lobectomia com istmectomia). O esvaziamento cervical, associado à tireoidectomia, foi feito em 158 pacientes (19,5\%). Observamos predomínio dos tumores classificados como T1 em 602 (74,6\%) dos pacientes. A hipocalcemia transitória foi a complicação mais frequente. Conclusão: os resultados mostram que o aumento mundial da incidência do câncer de tireoide alterou o perfil dos pacientes atendidos em serviço de referência. Além disso, ocorreram mudanças no tipo de tratamento cirúrgico empregado, com aumento no uso da tireoidectomia total em relação às parciais e subtotais e diminuição do uso de esvaziamento cervical eletivo para estas neoplasias.

Descritores: Glândula tireoide. Câncer de tireoide. Adenocarcinoma. Tireoidectomia.

\section{REFERENCES}

1. Cramer JD, Fu P, Harth KC, Margevicius S, Wilhelm SM. Analysis of the rising incidence of thyroid cancer using the Surveillance, Epidemiology and End Results national cancer data registry. Surgery. 2010;148(6):1147-52; discussion 1152-3.

2. Brasil. Ministério da Saúde. Instituto Nacional de Câncer José Alencar Gomes da Silva. Estimativa 2012: Incidência do câncer no Brasil [Internet]. Rio de Janeiro: INCA, 2011. [citado 2012 mar 8]. Disponível em: http://www.inca.gov.br/estimativa/2012/ estimativa20122111.pdf

3. Coeli CM, Brito AS, Barbosa FS, Ribeiro MG, Sieiro AP, Vaisman M. Incidência e mortalidade por câncer de tireoide no Brasil. Arq Bras Endocrinol Metab. 2005;49(4):503-9.

4. Kent WD, Hall SF, Isotalo PA, Houlden RL, George RL, Groome PA. Increased incidence of differentiated thyroid carcinoma and detection of subclinical disease. CMAJ. 2007;177(11):1357-61.

5. Chen AY, Jemal A, Ward EM. Increasing incidence of differentiated thyroid cancer in the United States, 1988-2005. Cancer. 2009;115(16):3801-7.

6. Enewold L, Zhu K, Ron E, Marrogi AJ, Stojadinovic A, Peoples GE, et al. Rising thyroid cancer incidence in the United States by demographic and tumor characteristics, 1980-2005. Cancer Epidemiol Biomarkers Prev. 2009;18(3):784-91

7. Aschebrook-Kilfoy B, Ward MH, Sabra MM, Devesa SS. Thyroid cancer incidence patterns in the United States by histologic type, 1992-2006. Thyroid. 2011;21(2):125-34

8. Zhu C, Zheng T, Kilfoy BA, Han X, Ma S, Ba Y, et al. A birth cohort analysis of the incidence of papillary thyroid cancer in the United States, 1973-2004. Thyroid. 2009;19(10):1061-6.

9. Liu S, Semenciw R, Ugnat AM, Mao Y. Increasing thyroid cancer incidence in Canada, 1970-1996: time trends and age-periodcohort effects. Br J Cancer. 2001;85(9):1335-9.
10. Simard EP, Ward EM, Siegel $R$, Jemal $A$. Cancers with increasing incidence trends in the United States: 1999 through 2008. CA Cancer J Clin. 2012. [Epub ahead of print].

11. American Thyroid Association (ATA) Guidelines Taskforce on Thyroid Nodules and Differentiated Thyroid Cancer, Cooper DS, Doherty GM, Haugen BR, Kloos RT, Lee SL, et al. Revised American Thyroid Association management guidelines for patients with thyroid nodules and differentiated thyroid cancer. Thyroid. 2009;19(11):1167-214.

12. Nixon IJ, Ganly I, Palmer FL, Whitcher MM, Patel SG, Tuttle RM, et al. Disease-related death in patients who were considered free of macroscopic disease after initial treatment of well-differentiated thyroid carcinoma. Thyroid. 2011;21(5):501-4.

13. Lang BH, Lo CY, Chan WF, Lam KY, Wan KY. Staging systems for papillary thyroid carcinoma: a review and comparison. Ann Surg. 2007;245(3):366-78.

14. Podnos YD, Smith D, Wagman LD, Ellenhorn JD. The implication of lymph node metastasis on survival in patients with welldifferentiated thyroid cancer. Am Surg. 2005;71(9):731-4.

15. Mazzaferri EL, Jhiang SM. Long-term impact of initial surgical and medical therapy on papillary and follicular thyroid cancer. Am J Med. 1994;97(5):418-28.

16. Tuttle RM, Ball DW, Byrd D, Dilawari RA, Doherty GM, Duh QY, et al. Thyroid carcinoma. J Natl Compr Canc Netw. 2010;8(11):122874.

17. Kowalski LP, Filho JG. Results of the treatment of locally invasive thyroid carcinoma. Head Neck. 2002;24(4):340-4.

18. Maia AL, Ward LS, Carvalho GA, Graf H, Maciel RMB, Maciel $L M Z$, et al. Nódulos de tireoide e câncer diferenciado de tireoide: Consenso Brasileiro. Arq Bras Endocrinol Metab. 2007;51(5):86793 
19. Pitoia F, Ward L, Wohllk N, Friguglietti C, Tomimori E, Gauna A, et al. Recommendations of the Latin American Thyroid Society on diagnosis and management of differentiated thyroid cancer. Arq Bras Endocrinol Metabol. 2009;53(7):884-7.

20. Filho JG, Kowalski LP. Postoperative complications of thyroidectomy for differentiated thyroid carcinoma. Am J Otolaryngol. 2004;25(4):225-30.

21. Lira RB, Carvalho GB, Carvalho AY, Gonçalves Filho J, Vartanian $J G$, Ikeda MK, et al. Mudanças no perfil de atendimento do Departamento de Cirurgia de Cabeça e Pescoço em um hospital de referência para câncer. Rev Bras Cir Cabeça Pescoço, 2012;41(1):1-4.

22. Davies L, Welch HG. Increasing incidence of thyroid cancer in the United States, 1973-2002. JAMA. 2006;295(18):2164-7.

23. Koh YW, Lee SW, Choi EC, Lee JD, Mok JO, Kim HK, et al. Prediction of hypothyroidism after hemithyroidectomy: a biochemical and pathological analysis. Eur Arch Otorhinolaryngol. 2007;265(4):4537.

24. De Carlucci D Jr, Tavares MR, Obara MT, Martins LA, Hojaij FC, Cernea CR. Thyroid function after unilateral total lobectomy: risk factors for postoperative hypothyroidism. Arch Otolaryngol Head Neck Surg. 2008;134(10):1076-9.
25. McHenry CR, Slusarczyk SJ. Hypothyroidisim following hemithyroidectomy: incidence, risk factors, and management. Surgery. 2000;128(6):994-8.

26. Miller FR, Paulson D, Prihoda TJ, Otto RA. Risk factors for the development of hypothyroidism after hemithyroidectomy. Arch Otolaryngol Head Neck Surg. 2006;132(1):36-8.

27. Vaiman M, Nagibin A, Hagag P, Kessler A, Gavriel H. Hypothyroidism following partial thyroidectomy. Otolaryngol Head Neck Surg. 2008;138(1):98-100.

28. Sippel RS, Chen H. Controversies in the surgical management of newly diagnosed and recurrent/residual thyroid cancer. Thyroid. 2009;19(12):1373-80.

Received on 20/10/2013

Accepted for publication 10/01/2014

Conflict of interest: none.

Source of funding: none.

\section{Mailing address:}

Renan Bezerra Lira

E-mail: renan.lira@accamargo.org.br 